\title{
Quality Science Education at Secondary School Level in Delta State: Are the Libraries and Science Books Available for Use?
}

\author{
Ajaja O. Patrick and Emperor Kpangban \\ Department of Science Education, Delta State University, Abraka, Nigeria
}

KEYWORDS Takeover; quantity; recommended; regularity; book types; senatorial

\begin{abstract}
The purpose of this study was to find out the state of science books in libraries in Public Schools in Delta State of Nigeria and to particularly determine the positioning of the libraries for the effective implementation of the senior secondary science curriculum - in the areas of kinds of books available, their quantity, quality and relevance. The design employed for the study was survey. To guide this study, five research questions were raised and answered. 90 Public secondary schools randomly selected from the three senatorial districts of Delta State were used for the study. Data were collected with questionnaire, interview and personal evaluation of the libraries in the selected schools. The major findings of the study are as follows: (1) The various groups which provide books to public schools in the state include; State government, Parent Teacher Associations (PTAs), School heads, Old Boys'/Girls' Associations, Individuals, other local Associations and Non-Governmental Organisations (NGOs). (2) Most of the schools with libraries are those already established before the government takeover of schools in Nigeria. (3) The existing libraries grossly lack basic facilities like tables, chairs, shelves, books and Librarians. (4) In schools where libraries exist, only $14.3 \%$ of the students claimed that they used the libraries often, while as high as $54 \%$ of the students do not go to the libraries. (5) None of the schools created adequate opportunities for students to use the libraries. (6) For the schools that have libraries, they received their last stock of new science books about 26 years ago. (7) Most of the science books found in the libraries are outdated and no longer relevant for the teaching and learning of the current science curriculum. It is concluded that successive governments in the state have not been serious with the development of libraries which will nourish quality science education in the state.
\end{abstract}

\section{INTRODUCTION}

One thing everyone who passed through secondary education remembers is how some students, particularly elite's children, seemed to learn science so easily while others had to work harder to learn as well. It is common experience among junior secondary school students in class one to be told stories of science fiction by their mates who had read science picture books at home. Some can vividly tell the story of dustwhere it comes from, its longevity, how it affects sunset and sunrise, and the role it plays in the formation of raindrops. Good science books promote scientific literacy, and foster an understanding and appreciation of science in readers of all ages. Both in the classroom and real life, it seems that someone has more abilities than others (Borich, 2004). The variation in ability may have arisen as a result of previous experience. This observation often has been a source of anxiety, concern and jealousy among learners.

Correspondence Address: Dr. Ajaja O. Patrick Department of Science Education, Delta State University, Abraka, Nigeria

Telephone: 08037230550

E-mail: osawaruajaja@yahoo.com
We all know from personal experience in school, disciplines, hobbies, sports and even interpersonal relationships that the degree of ability depends on the circumstances and conditions under which an individual is trained. A number of today's university undergraduates missed out in attending secondary schools that had great libraries where science books are readily available. A high percentage of these secondary schools students ended up offering subjects in arts. The few students who manage to offer science subjects show tremendous weakness in the subjects. McKesson Health Solutions (2003) noted that pleasant, happy experiences with books among other things in formative years are vital for a continuing love and curiosity; an attribute of science into adulthood This remark agrees with the findings of Ujie and Krashen (2003) and the note by Omar (2006).

The powerhouse of science education is the library stocked with relevant and recent science books. Any institution lacking in facilities expected in the science section of a library, is assumed not to be ready for the business of science education. As pointed by UNESCO, books on science subjects help to deepen the pupils' understanding of science, awaken their interest and 
encourage them to take up scientific disciplines as careers. In the words of McKesson Health Solution (2003): "as the pages of a book are turned, a child's world is broadened: it sparks children creativity and imagination; introduces them to new people, places, and ideas". A standard secondary school with the intension of achieving the goal of effective teaching and learning of science, should have a standard library stock with current books in science.

UNESCO is of the view that books have always been and still are essential tools in teaching. Omar (2006) noted that you will need book to support your science students and you will need books to support research and science teaching. It is assumed that old books seldom have the modern approaches to the teaching and learning of science subjects. It is generally believed that stimulation to discovery in science can hardly be achieved if students at all levels are not adequately equipped with recent science books into which they can delve and find things out by themselves. There is a spin off when a library stocked with recent science books is put into good use. A good library nurtures good writing. Science education can be lucidly presented to secondary school students so as to draw more brilliant students to the study of science and applied fields.

Kolade (2006) noted that in today's world, a graduate is expected to possess the following skills and qualities:

a) Sound knowledge and understanding of his discipline;

b) A liberal education in order to be able to broadly interact and bring that perspective to problem solving;

c) Computer literacy and ability to use the computer in tackling various tasks effectively;

d) Demonstration of confidence and communication ability both orally and in written form; and

e) Character.

All these tasks are accomplished with books. This study emanated from the ever declining facilities for teaching and learning science subjects in our schools particularly lack of current and relevant science textbooks. It is stressed at this point that a library rich in science education textbooks will develop in its users, imagination and better understanding of life and nature. The state of science books in our secondary school libraries which is the focus of this study has suffered persistent decline since the government take-over of schools in 1973. Before the take-over, all the schools which existed as at then had standard libraries properly stocked with recent and relevant science books. Students read in library at their free periods and borrow recent science textbooks relevant to their subjects of choice. Students exhibited interest, enthusiasm and creativity and the quality of works done by science students were excellent. It is most unfortunate to note that 33 years after the takeover of schools, almost all the secondary schools in the country lack libraries and where relevant science textbooks are stocked. Where they exist all the books are outdated. The consequences of these have been very poor interest and lack of creativity among science students, heightened examination malpractice, poor performance in science subjects and very low number of students willing to study science at the tertiary level of education.

Oye (2006) while lamenting the effects of examination malpractice on our educational system stated that the failure rate among candidates who enters universities with very high University Matriculation Examination (UME) scores is very disturbing. He further noted that $10 \%$ of candidates who scored more than 280 points in the UME scored less than $25 \%$ in the Post UME university-conducted screening test.

In this paper, attempt will be made to take a survey of the libraries in our schools with the intention of determining the state of science textbooks in them and how prepared they are in boosting the kind of teaching and learning required in this century science.

\section{Problem of the Study}

This study grew out of the dilemma the contemporary science teachers find themselves in recent times - because of declining performance of the science students. At present, most science students are no longer able to do take-home assignments either because they have no place to source for information to enable them do the assignments or their parents are too poor to buy them science books recommended for the subjects. If the libraries were stocked with relevant science books, students would have looked for reference materials there. This has created a generation of students who do not read but depend only on what the teachers give. The 
statement of the problem, therefore, is: will the evaluation of the state of science books in libraries in our schools produce ideas on how to revitalize the school libraries and change the science students' attitude on the use of library for information gathering?

\section{Purpose of the Study}

The purpose of this study was to find out the state of science books in our school libraries. Emphases was on how many schools have libraries, how often they are used, as well as what the ages the science books are, and how relevant the science books are for the teaching and learning of science in this country.

\section{Research Questions}

The following research questions were asked to guide this study.

1. How are libraries distributed among public schools in the state?

2. How often do science students use libraries?

3. How many schools have free periods/library periods in their school timetables?

4. How long ago did schools receive new science books in their libraries?

5. How many relevant science books for teaching and learning of current science syllabuses are found in the libraries?

\section{METHODOLOGY}

The design employed to carry out this study was the survey. The instruments used for the study include questionnaires (teacher and student types), oral interviews and personal assessment of the state of science books in school libraries. The questionnaires mainly have items which generated data for answering the stated research questions. The content validity of the questionnaires was established by making use of three experienced science teachers for their comments. Borich (2004) stated that a test is valid if it measures what it is supposed to measure. The reliabilities of the questionnaires were determined by using interater reliability approach. This approach was adopted based on the recommendation of Thorndike and Hagen (1977). They recommended that the pooling of the ratings of several judges about an individual will produce a composite that is more reliable. The reliabilities of the teacher and students' questionnaires were 7.1 and 7.4 respectively.

The samples of the study include 90 public secondary schools randomly selected from the three senatorial districts in Delta State (Delta North, Delta South and Delta Central), 270 science teachers ( 3 from each school) and 900 students; 10 from each school offering the three sciences (Chemistry, Biology and Physics). To collect data from the schools, two types of questionnaire were mainly distributed. They are the teacher and student questionnaires. Other methods used for the collection of data include interview and personal examination of science books in the libraries. The responses and observations are arranged in tables 1-7 in order to answer the stated research questions.

\section{RESULTS}

Shown in table 1 and figure $1,80 \%$ of science books in public secondary schools are provided by the state government. This is followed by PTA who contributes $10 \%$. Other contributors include; school heads 5\%, Old Boys/Girls

Table 1: Providers of books to public schools in Delta State

\begin{tabular}{llcll}
\hline $\begin{array}{l}\text { S. } \\
\text { No. }\end{array}$ & Name of providers & $\begin{array}{c}\% \\
\text { contribution }\end{array}$ & $\begin{array}{l}\text { Regularity of } \\
\text { contribution } \\
\text { before 1973 }\end{array}$ & $\begin{array}{c}\text { Regularity after } \\
\text { 1973 till date }\end{array}$ \\
\hline 1 & State Government & 80.0 & Yearly & $\begin{array}{l}\text { Yearly up to 1983. } \\
\text { Now once a while } \\
\text { Once a while }\end{array}$ \\
2 & Parent Teacher Association (PTA) & 10.0 & Yearly & Only a copy for \\
3 & School Heads (Principlas) & 5.0 & Always & On demand by schools \\
4 & Old Boys/Girls Associations & 2.5 & Once in 3 years & Once in ten years \\
5 & Individuals (philanthropists) & 1.0 & Once a while & Once in ten years \\
6 & Other Local Associations & 1.0 & Once a while & Do not come again \\
7 & NGO's (Non Governmental Organisations) & 0.5 & Once a while & \\
\hline
\end{tabular}


Table 2: Distribution of libraries in schools

\begin{tabular}{lccccc}
\hline Age of school & No. & $\begin{array}{c}\text { Sch. with } \\
\text { library }\end{array}$ & $\begin{array}{c}\text { Sch. without } \\
\text { library }\end{array}$ & $\begin{array}{c}\text { \% with } \\
\text { library }\end{array}$ & $\begin{array}{c}\text { \% without } \\
\text { library }\end{array}$ \\
\hline 30 years and above & 27 & 27 & 0 & 100.0 & Nil \\
15-25 years & 54 & 15 & 39 & 27.8 & 72.3 \\
Less than 15 years & 9 & 0 & 9 & Nil & 100.0 \\
\hline Total & 90 & 42 & 48 & 46.7 & 53.3 \\
\hline
\end{tabular}

Association $2.5 \%$, individuals $1 \%$, other local associations $1 \%$ and NGOs' $0.5 \%$. The contribution of science books to schools by other groups other than government started declining after 1973 government take-over of schools. The government still supplied science books to schools up to 1983 when it practiced free education. The school heads still manage to provide few copies of recommended science books till date.

It was found that only $46.7 \%$ of the schools have libraries while as high as $53.3 \%$ do not have libraries as shown in table 2 . The table also shows that all the schools established 30 years and above ago have libraries while among those established between 15-25 years ago, only $27.8 \%$ have libraries. All the schools established less than 15 years ago have no libraries.

Shown in table 3 , the facilities available in school libraries indicates that only $33.7 \%$ of the schools with libraries have chairs, tables and book shelves with books arranged, $10 \%$ have

Table 3: Structure of school libraries in Delta State

\begin{tabular}{lcc}
\hline Facilities available & No. of schools & $\%$ \\
where they exist & & \\
\hline With (Chairs, tables, shelves with books arranged) & 33 & 36.7 \\
Only reading rooms with few tables and chairs & 9 & 10.0 \\
Few school books and records in stores & 48 & 53.3 \\
Government employed librarians & 0 & 0.0 \\
\hline
\end{tabular}

Table 4: Regularity in the use of library

\begin{tabular}{lcc}
\hline Mode of use & $\begin{array}{c}\text { No. of Respondents } \\
\text { (Students) }\end{array}$ & $\%$ \\
\hline Often & 60 & 14.3 \\
Once a while & 135 & 32.1 \\
Never & 225 & 53.6 \\
\hline Total & 420 & 100.0 \\
\hline
\end{tabular}

reading rooms with few chairs and tables, while $53 \%$ keep their science books in the stores. All the schools with libraries lack government employed librarians.

On the use of the libraries by students shown in table 4 , it was found that only $14.3 \%$ of the students use the library regularly. $32.1 \%$ of the

Table 5: School time provisions encouraging use of library

\begin{tabular}{lrrrrrrr}
\hline Time table provision & \multicolumn{5}{c}{ Class and No. of periods per week } & \multirow{2}{*}{ No. of schools } \\
\cline { 2 - 7 } & $J S I$ & $J S I I$ & JSIII & SSI & SSII & SSIII & \\
\hline Free Periods & 2 & 2 & Nil & Nil & Nil & Varied & 90 \\
Library period & Nil & Nil & Nil & Nil & Nil & Nil & 90 \\
\hline
\end{tabular}

Table 6: Stocking of libraries with new books by government and others.

\begin{tabular}{|c|c|c|c|c|c|}
\hline Period & Providers & Subject areas & Quantity & Time & $\begin{array}{l}\text { No. of } \\
\text { schools }\end{array}$ \\
\hline 26 years ago & UPN Govt. \& Others & All science subjects & Numerous & All time & All \\
\hline $16-25$ years ago & $\begin{array}{l}\text { PTA, others \& } \\
\text { school principals }\end{array}$ & $\begin{array}{l}\text { Maths, Chemistry, } \\
\text { Biology, Physics and } \\
\text { Integrated Science }\end{array}$ & $\begin{array}{l}1 \text { copy per per } \\
\text { level per subject }\end{array}$ & $\begin{array}{l}\text { All times and } \\
\text { change in syllabus }\end{array}$ & All \\
\hline $6-15$ years ago & School principals & Maths, & 1 copy per level & Change in syllabus & All \\
\hline$£ 5$ years & School principals & Maths, & 1 copy per level & Change in syllabus & All \\
\hline
\end{tabular}


students use the library occasionally, while $53.6 \%$ of them do not use the library at all.

There are no provisions in the school timetables to encourage students use of the libraries. Table 5 shows that JSS I and II just have two free periods per week in the school time table. JSS III, SSI and SSII have no free periods. In SSIII, the number of free periods are varied because the students offer different school subjects. The school time tables have no library periods for any class.

The last time the government provided large quantities of science books to schools was 26 years ago, shown in table 6 by UPN government led by late Professor Ambrose Ali. It was found that between 16-25 years ago, PTA, school principals and others provided books in mathematics, chemistry, biology, physics and integrated science, only a copy per book per level always and when there was a change in syllabus. Between now and 15 years ago, only principals manage to provide a copy of mathematics books per level when there is a change in syllabus as shown in figure 2.

Shown in table 7, it was found that all the books in the school libraries treated contents in 6-5-4 system of education curriculum. Most of the books are outdated, published in the sixties and seventies. Contents of the available science

Table 7: Relevant book types in libraries for teaching SSCE science syllabuses

\begin{tabular}{|c|c|c|c|c|c|}
\hline & Books categories & $Q$ & Syllabus emphasized & $\begin{array}{l}\text { Relevance for } \\
\text { teaching SSCE syllabus }\end{array}$ & When published \\
\hline \multicolumn{6}{|c|}{ A Biology } \\
\hline & * Form and function & Few & 6-5-4 Curriculum & Partial & In the $1960 \mathrm{~s} \& 1970 \mathrm{~s}$ \\
\hline & * Ecology & Nil & - & - & - \\
\hline & * Genetics & Nil & - & - & - \\
\hline & * Objective & Few & 6-5-4 Curriculum & Partial & In the $1960 \& 1970 s$ \\
\hline & * Practical & Few & 6-5-4 Curriculum & Partial & In the $1960 \& 1970 s$ \\
\hline \multicolumn{6}{|c|}{$B$ Chemistry } \\
\hline & $\begin{array}{l}\text { * General \& Inorganic } \\
\text { chemistry }\end{array}$ & Few & 6-5-4 Curriculum & $\begin{array}{l}\text { Relevant if IUPAC } \\
\text { name can be inferred }\end{array}$ & In the $1970 \mathrm{~s}$ \\
\hline & * Organic Chemistry & Nil & - & - & - \\
\hline & * Volumetric Analysis & Few & $\begin{array}{l}\text { 6-5-4 Curriculum } \\
\text { name can be inferred }\end{array}$ & Relevant if IUPAC & In the $1970 \mathrm{~s}$ \\
\hline & * Qualitative Analysis & Few & 6-5-4 Curriculum & Partial & In the $1960 \& 1970 s$ \\
\hline & * Objective Chemistry & Few & 6-5-4 Curriculum & Partial & In the $1960 \& 1970 s$ \\
\hline \multicolumn{6}{|c|}{ C Physics } \\
\hline \multicolumn{6}{|c|}{ * Mechanics \& } \\
\hline & Thermodynamics & Nil & - & - & - \\
\hline & * Electricity and waves & Nil & - & - & - \\
\hline & * Applied physics & Nil & - & - & - \\
\hline & * Practical physics & Few & 6-5-4 Curriculum & Partial & In the $1960 \& 1970$ s \\
\hline & * Objective physics & Few & 6-5-4 Curriculum & Partial & In the $1960 \& 1970$ s \\
\hline
\end{tabular}

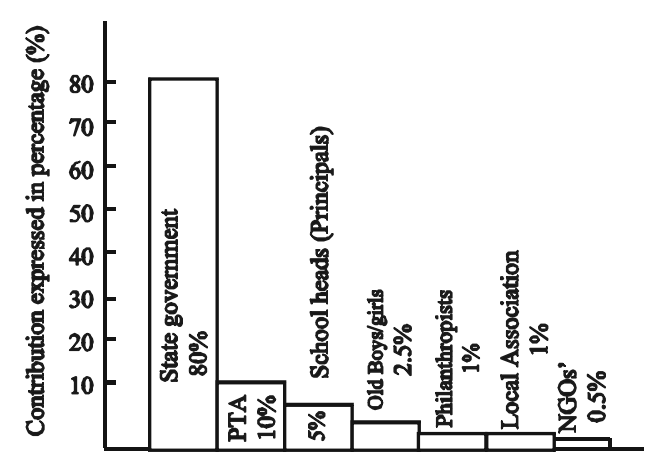

Providers of Science Books.

Fig. 1. Contribution of science books to schools by groups before government takeover in 1973

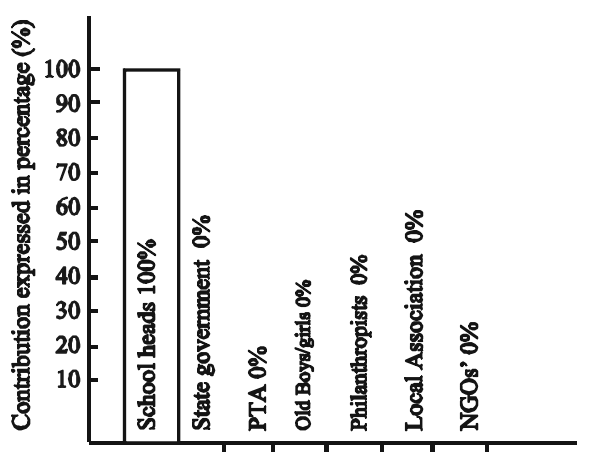

Providers of science books

Fig. 2. Contributions of science books to schools now. 
textbooks are not very relevant for the teaching and learning of contents in the current science curriculum used in our schools.

\section{DISCUSSION}

Obayan (2006) noted that it is the quality of standards that determines the validity of the process. It therefore follows that the quality of the science books in our libraries determines to a great extent how valid the teaching and learning of sciences is. Science books which are mostly stored in the libraries are the underlying storehouse of knowledge, information and ideas (Paul, 2002 and Omar, 2006). Kolade (2006) stated that the contents of books are available for days, weeks, or years outliving the authors and the publishers. Ivowi (2004) noted that theory and practical are integrated and open-ended questions raised in science books, challenge and stimulate students' interest. McKinney and Jones (1998) in their remarks noted that books are of value. It has been suggested that books can be used to develop critical thinking skills (Holmes and Ammon, 1985; Brown, 1986; Lehman and Hayes, 1985; Mosher, 1986; Rieken and Miller, 1990 Masalki, 2001 and McKesson Health Solution, 2003). Kirsch, Jungeblut, Jenkins, and Koistad (1993) still on importance of books noted that if comic books are less available for children it explains class difference in literacy development.

The first finding of this study indicates that most of our schools do not have libraries. As much as $53.3 \%$ of the sampled schools do not have libraries. The few schools which indicated that they have libraries, are those established over 33 years ago by the missionaries or the governments immediately after independence. Most of the public secondary schools established after government takeover of schools in 1973 operate without libraries. The government merely built schools based on demand for education by the society without the provision of library facilities. From the point of takeover of schools, the government funding of education continued on a downward decline yearly. This can be seen in the persistent decline in the ability of school heads to provide recommended science textbooks for teaching school science subjects. The libraries in the old schools have nothing to show for their ages. Most of the seats and tables are broken. The few science books available are outdated and their contents no longer in line with the present senior secondary school curriculum. The librarians in the old schools have all retired without replacement. The old science books are left to waste away without anybody entrusted with the responsibility of taking care of them. This development may well explain the persistent poor performances among secondary schools science students noticed by Urevbu (1997) and Oye (2006). With this type of development, our quest for rapid technological and scientific development is most likely to drag on for a long period.

Another finding of this study indicates that science students hardly make use of the libraries in schools where they exist. The reasons for this are not far-fetched. Both the school and the government are to be blamed for the development of such attitude. The school timetables do not create reasonable openings for all the students to visit the libraries and thus form the habit of reading there. Most of the students in the public schools are occupied by teachers of school subjects right from the time the school opens to closure. These regularly occupied students can never go to the libraries. For schools that have no libraries, the concept of library to the students there, is an illusion. Such students do not know anything about the library and so they do not go to libraries. In schools that have libraries, one other reasons why the students do not go to libraries, is because of the nature of science books and other materials available there. The contents of most of the books in the libraries are no longer relevant for teaching and learning of current science subjects contents. When there is a relevant textbook for teaching science, it is the subject teacher's copy and so not available for students to use. This finding agrees with Ajaja's (2002) remarks that all facilities for teaching and learning science, textbooks inclusive, are grossly inadequate in our schools. This finding is not in conformity with standards and expectations in the use of libraries by science students world wide. World wide, library serves as the store of knowledge for all disciplines. Omar (2006) commenting on the importance and use of libraries noted that there is a spin off where stocked library is put into good use. A good library spurs creativity and writing. Reinman (2005) in his own contribution, noted that the library is the primary source of information for students assignment.

The third major finding of this study is the revelation that the last time government supplied science books in bulk to schools was 26 years 
ago. This was during the UPN led government in Bendel State. Delta State was carved out of the former Bendel State. Shortly after the supply of these books between 1979 and 1983, the nation experienced very serious economic recession. Our currency was seriously devalued. The value of our money was so low that it could not buy much. The policy prohibiting the purchase and distribution of books to schools was put in place and the practice still exists to date. This policy negates the findings of Paul (2002) who noted that; "walk into any classroom and you will find textbooks very much in evidence". He found that $78 \%$ of teachers use textbooks in their classroom and that almost half of the teachers indicate that they use textbooks every day.

\section{CONCLUSION}

Standard libraries stocked with relevant and current science books are very important if effective teaching and learning of sciences is to be sustained. Science books are needed in secondary schools to support students learning and teachers teaching. New science books reflect recent developments in science and efforts should be made to stock them in the school libraries.

It is very clear from the findings of this study that successive governments have not been serious with the development of libraries in our schools. If the declining creativity among science students in the country has to improve, the issue of development of standard libraries stocked with relevant science books must be taken very seriously. It will be absolute nonsense to be craving for science and technology development without providing current science books in the school libraries from where the teachers and students will know where the world is.

\section{RECOMMENDATIONS}

From the findings of the study, the following recommendations are made:

Firstly, the education policy makers in the country should put in place a regulation requiring government and other school owners to first establish a standard library before approval.

Secondly, all school owners should as a matter or urgency go back to their institutions, to establish new standard libraries or refurbish existing ones stocked with science books and facilities.

Thirdly, school timetables should provide adequate openings to enable all categories of students make use of the libraries.

Fourthly, all book donors should be encouraged to do more. This can be done by school heads of institutions who benefited writing letters of appreciation to such donors.

Fifthly, the government should as quickly as possible employ librarians to take care of the libraries in public schools

\section{ACKNOWLEDGEMENT}

We remain grateful to all the school heads, staff and students of all the schools in the three senatorial districts in Delta State, used for the study for their wonderful co-operation, interest and respect. We are short of words to express our gratitude. We specially thank the school heads and teacher librarians for their willingness to give out information on request and conducting us round the school libraries. Thanks a million. We love you all.

\section{NOTES}

(i) JSI, II \& III. This Means Junior Secondary Class I, II, and III

(ii) SSI, II \& III. Means Senior Secondary Class I, II and III.

(iii) NGO. Means Non-Governmental Organisation

(iv) PTA. Means Parent Teachers Association

(v) Old Boys/Girls. People who graduated from a Particular school some years ago.

(vi) SSCE. This means Senior Secondary Certificate Examination.

(vii) 6-5-4 Curriculum. This is the curriculum used for the system of education where the primary level lasts for six years, secondary level lasts for five years and the tertiary level lasts for four years.

(viii) Science Curriculum. This is the expected learning outcomes used for teaching science subjects like; Biology, Chemistry, and Physics and Integrated Science.

(ix) Senatorial district. This is made of a group of local government areas which produce one senator for the senate chamber of the National Assembly.

\section{REFERENCES}

Ajaja, O.P. 2002. "Assessment of biology study support environment in our schools", (pp. 215-218) in Proceedings of the $43^{\text {rd }}$ Annual Conference and Inaugural Conference of CASTME Africa.

Borich, G.D. 2004. Effective teaching methods fifth edition New Jersey: Pearson education, Inc.

Brown, L. 1986. "Developing thinking and problem solving skills with trade books." Childhood Education. 63: 102-107.

Holmes, B.C., and R. I. Ammon. 1985. "Teaching content 
with trade books." Children Education, 61: 366370 .

Ivowi, U.M.O. 2004. "Problems and prospects in the teaching/learning of science in secondary school", (pp. 384-406) in B. B. Akpan (ed.), Perspectives on Education and Science Teaching Edited by Abuja: Foremost educational services Ltd.

Kirsch, I., A. Jungehut, L. Jenkins and A. Kolstad. 1993. Adult literacy in America. Washington, D.C.: U.S. Department of education.

Kolade, M. 2006. "Quality education inspired by books and book publishing." Paper presented as the $6^{\text {th }}$ NAPEUAP Leadership forum in Calabar.

Lehman, B.A., and D. Hayes. 1985. "Advancing critical reading through historical fiction and biography." The Social Studies. 76: 165-169.

Masalki, K.W. 2001. "Examining the Japanese history controversies." <www.indiana.edu/ japan> Accessed 30 March, 2007.

McKesson Health Solution, L.L.C. 2003. "The importance of books." <www.med.umich.edu. ||.br|pa|pa-litimpor-pep> Accessed 30 March, 2007.

McKinney, C.W. and H. J. Jones. 1998. "Effects of a children's books and a traditional textbook on fifthgrade students achievement and attitude towards social studies", (pp. 66-73) in J. H. Mc Millan and J. F. Wergin. Understanding and Evaluating Educational Research. New Jersey: Prentice Hall, Inc.

Mosher, L.J. 1986. "Using children's literature to develop thinking skills in young children." Dissertation abstracts international. 47, 2439A.

Obayan, A, 2006.. "Implementing quality education standards: consideration of private university initiatives." Paper presented at the $6^{\text {th }}$ NAPE UAP Leadership forum in Calabar.

Omar, M.A. R. 2006. "Maintenance of educational standard and ethics towards better productivity." Paper presented at the $6^{\text {th }}$ NAPEUAP Leadership forum in Calabar.

Oye, I. 2006 "Quality education standards: Need for a refined university admission process." Paper presented at the $6^{\text {th }}$ NAPEUAP Leadership forum in Calabar.

Paul, A. 2002. "Importance of textbooks: (a final thought)." <www.allbusines.com/educational service> Accessed 30 March 2007.

Reinman, S. 2005. "The Declining importance of books: Get over it." <www.google.com> Accessed 30 March, 2007.

Rieken, T.J. and M. R. Miller. 1990. "Introduce children to problem solving and decision making by using children's literature." The Social Studies, 59-64 \& 81 .

Thorndike, R.L. and E. P. Hagen. 1977. Measurement and Evaluation. New York: John Wiley and Sons.

Ujie, J., and S. D. Krashen. 2003."Comic book reading, reading enjoyment and pleasure reading among middle class and chapter 1 middle school students", (pp. 162-164) in L. S. Lyne, L A Cross Section of Educational Research Journal Articles for Discussion and Evaluation. $2^{\text {nd }}$ Edition. California: Fred Pyrczak, Publisher.

Urevbu, A.O. 1997. "Creating the school we deserve", in University of Benin Inaugural Lectures Series. 